\title{
Using UTAUT Model to Predict Social Media Adoption among Indonesian SMEs
}

Fatmah Amir Abdat ${ }^{*}$

Faculty of Economics and Business, Universitas Mercu Buana, Jakarta, Indonesia

$\begin{array}{ll}\text { DOI: } 10.36348 / \text { sjef.2020.v04i10.003 } & \text { | Received: } 02.08 .2020 \text { | Accepted: } 09.08 .2020 \text { | Published: } 30.10 .2020\end{array}$

*Corresponding author: Fatmah Amir Abdat

\section{Abstract}

The purpose of this paper was to predict the factors that influence the adoption of Social Media Apps (SMA) among Indoneisan SMEs to promote and market their business using UTAUT (Unified Theory of Acceptance and Use of Technology theory) approach. These factors include performance expectancy, effort expectancy, social influence, and facilitating conditions. To fulfill these aims, a quantitative research was adopted. Data were taken using a questionnaire from total of 162 respondents, namely the owner or manager of SMEs. The sampling technique used was non-probability sampling. Then, the data was tested using Partial Least Square. The findings of this study revealed that the model was able to explain $61 \%$ of the variance in behavioral intention. Result showed that the variables such as performance expectancy, social influence, and facilitating conditions had positive and significant effect on behavioral intention to adopt social media apps. On the other hand, effort expectancy had no significant effect on behavioral intention. Based on results, theoretical and practical implications are provided for scholars, SMEs' owner and manager.

Keywords: Social media adoption, UTAUT, Performance expectancy, Social Influence, Facilitating condition.

Copyright @ 2020: This is an open-access article distributed under the terms of the Creative Commons Attribution license which permits unrestricted use, distribution, and reproduction in any medium for non-commercial use (NonCommercial, or CC-BY-NC) provided the original author and source are credited.

\section{INTRODUCTION}

One of the biggest drivers of economic growth in the world is SMEs. In conditions that are competitive and modern, business characteristics continue to change [1]. Therefore, SMEs need marketing tools that are not only effective, but also efficient in improving their market and financial performance. Social media is a popular tool used by Small and Medium Enterprises (SMEs) because of the easy technical requirements and low cost [2]. A number of studies have found that SMEs use social media for various organizational purposes such as marketing, communication, sales, advertising, innovation, problem solving, customer service, human resources, information technology, driving cultural change, advertising on social networks and internet marketing $[3,4]$.

Some previous research on social media in SMEs including the effect of social media on performance [5-10] social media for SMEs knowledge management [11]; social media for recruitment in SMEs [12]; and social media as tool for facilitating knowledge creation and innovation in SMEs [13].
Some previous studies also looked at factors that influenced social media adoption in SMEs [6, 14, $15,16,17,10,18]$. Most of the research was carried out in developed countries $[5,19,20,21,15,16,17,18,22]$ and only few research has been done in developing countries $[6,14,18]$, where no one has used the UTAUT model approach in predicting the factors of social media adoption. We see that very little research has focused their studies on SME entrepreneurs' intentions to adopt social media to market their products using UTAUT model as a vacancy or research gap that needs to be investigated further. This paper aims to identify important factors that influence the adoption of social media by SME entrepreneurs with UTAUT - A Unified Theory of Acceptance and Use of Technology (UTAUT) Approach.

The purpose of this study is to predict the factors that influence the adoption of social media among SMEs in Indonesia with the Unified Theory of Acceptance and Use of Technology Theory approach, where based on UTAUT theory, these factors include performance expectancy, effort expectancy, social influence, and facilitating conditions. 


\section{LITERATURE REVIEW}

\section{Unified Theory of Acceptance and Use of Technology (UTAUT)}

The Unified Theory of Acceptance and Use of Technology (UTAUT) was first discovered by Venkatesh [23] and until now it has been used extensively in various studies and in various countries. UTAUT model is used to predict the factors that influence the acceptance and adoption of a technology, where the model is a combination of 8 previous theories, such as Motivational Model, the Theory of Planned Behaviour (TPB), a combined TBP/TAM, the Model of PC Utilization, Innovation Diffusion Theory (IDT), and Social Cognitive Theory (SCT). Moreover, UTAUT was reported to perform better compared to the eight individual models with an adjusted $\mathrm{R}^{2}$ of $69 \%$.

Recently, to assess intention to use technology, UTAUT is considered as the most valid and recent technology adoption model used [24]. Some recent studies examined the adoption of mobile application technology that used UTAUT, including research on: adoption of mobile games [25]; mobile banking [26, 27, $28,29,30]$ mobile payment [31-34], mobile shopping apps [35, 36]; mobile commerce [37]; library mobile application [38]; mobile health and diet applications [39-41] social media application [42, 43, 44, 45] hotel reservation mobile app [46]; Mobile learning and knowledge transfer [47, 48] car-sharing app [49]; and virtual tour-guiding platform [50].

Other than mobile applications, the UTAUT model is also used in explaining behavioral intention to use technology in other various fields, such as the use of big data techniques in service companies [51]; adopt self-service parcel services for last-mile delivery [52]; urban delivery drivers' intention to adopt electric trucks [52]; internet banking adoption [53, 54, 55], user acceptance and use of open government data (OGD) / egovernment $[56,57,58,59,60]$ intention to use an enterprise resource planning (ERP) system [61, 62], intention to use Airline Companies' e-services [63]; acceptance of automated road transport systems (ARTS) [64]; intention to adopt technology in medical or health field $[65,66,67,68,69,24]$ adoption of online tax filing [70]; adoption of e-book [71, 73] decision to use automated public transport [73]; and rural households' renewable energy usage intention [74].

In UTAUT model, Performance expectancy, effort expectancy, social influence and facilitating conditions were stated as the four main variables that become direct determinants of behavioral intentions. Moreover, several factors such as sex, age, experience, and voluntary use, in turn, moderating the construct [23]. Performance expectancy is defined as the degree to which user believes that using a new technology or system will help to accomplish tasks with excellent performance [75]. Besides that, effort expectancy is defined as the degree of how easy technology is to use, which will have a positive effect on the intended use [5]. In other than that, social influences is defined as the degree of others believe the user should adopt the new system or technology [52] and facilitating condition refers to the level where an individual believes that an institutional and technical infrastructure exists to help the use of the system [24].

Gupta, Manrai, and Goel [27] found that performance expectancy, effort expectancy, social influence and facilitating conditions are direct determinants of behavioural intention to adopt payments bank by Indian customer. Arif, Ameen, and Rafiq [77] found that performance expectancy, effort expectancy and social influence are significant predictors of student behavioural intention to use AIOU Web-based services in Pakistan. Besides that, Kurfal1, Arifoğlu, Tokdemir, and Paçin [78] also found that performance expectancy, social influence, and facilitating conditions have a positive effect on behavioral intention to use e-government services in Turkey. Based on the literature, the following hypothesis was proposed:

H1. Performance expectancy positively affects social media adoption among Indonesian SMEs

H2. Effort expectancy positively affects social media adoption among Indonesian SMEs

H3. Social influence positively affects social media adoption among Indonesian SMEs

H4. Facilitating condition positively affects social media adoption among Indonesian SMEs

Based on the literature review, a conceptual framework is showed in figure 1.

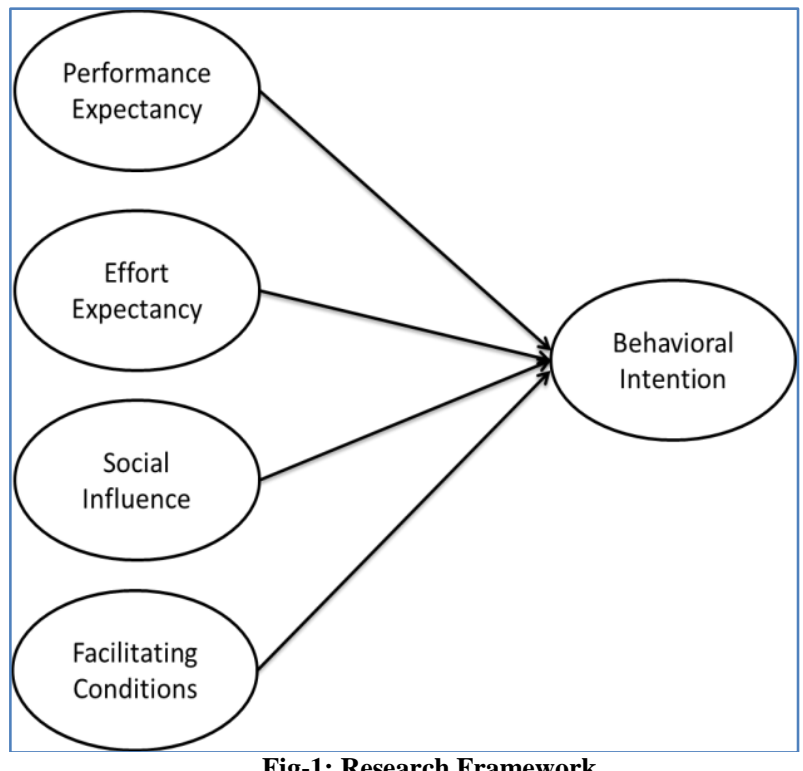

Fig-1: Research Framework

\section{RESEARCH METHODS}

This research used a quantitative approach, in which the research design used is cross-sectional and conclusive, with a type of causal research. In addition, 
this research method used survey methods. The population in this study are all SMEs domiciled in Jabodetabek Indonesia, who have accounts and use social media in promoting their products. In total, the research samples obtained were 162 respondents. The sampling method used was non-probability. Measurement items for performance expectancy (PE), effort expectancy (EE), social influence (SI) and facilitating conditions (FC) were adapted from Venkatesh [23]. Data collection is done by selfadministered questionnaire [79], where respondents answer questions that have been arranged in the form of choices and scale questions using a Likert scale (1-5), ranging from 1="strongly disagree" to 5="strongly agree". Data analysis method in this research is SEMPLS with the help of WarpPLS 6.0 software.

\section{FINDINGS AND DISCUSSION}

Model Fit and Quality Indiced. First of all, it is necessary to do a model fit test to see the suitability of the model built in the study. Thus, the suitability of the relationship between variables in research can be seen if the research model is said to be good. In this study, the use of WarpPLS 6.0 has provided calculation results that indicate the criteria used to assess whether the model is appropriate. From the test results, it is known that each value meets the ideal criteria, so it can be concluded that the overall research model is good and appropriate. For more information, fit model test results can be seen in Table 1 .

Table-1: Research Model Fit Test

\begin{tabular}{|l|c|c|}
\hline & Value & Ideal \\
\hline Average path coefficient (APC) & $\mathrm{P}<0,001$ & $<=0.05$ \\
\hline Average R-squared (ARS) & $\mathrm{P}<0,001$ & $<=0.05$ \\
\hline Average adjusted R-squared [82] & $\mathrm{P}<0,001$ & $<=0.05$ \\
\hline Average block VIF (AVIF) & 2.112 & $<=3.3$ \\
\hline Average full collinearity VIF (AFVIF) & 2.268 & $<=3.3$ \\
\hline Sympson's paradox ratio (SPR) & 1 & 1 \\
\hline R-squared contribution ratio (RSCR) & 1 & 1 \\
\hline Statistical suppression ratio (SSR) & 1 & $>=0.7$ \\
\hline Nonlinear bivariate causality direction ratio (NLBCDR) & 1 & $>=0.7$ \\
\hline
\end{tabular}

\section{Convergent Validity and Reliability}

Average Variance Extracted (AVE) value shows that all reflective constructs have AVE values $\geq$ 0.50 . The AVE results show that all indicators have met the specified value standards, so the convergence of indicators is valid or acceptable and it can be stated that all indicators that measure constructs have met the conditions of convergent validity. In addition, the results of the Composite Reliability (CR) data show that all values were above 0.8 meaning high reliability. The reliability test was strengthened with Cronbach's Alpha (CA), where the results showed high reliability. The data can be seen in Table 2 .

Table-2: Convergent Validity and Reliability

\begin{tabular}{|c|c|c|c|}
\hline & AVE & CR & CA \\
\hline Performance Expectancy (PE) & 0.542 & 0.902 & 0.873 \\
\hline Effort Expectancy (EE) & 0.790 & 0.938 & 0.911 \\
\hline Service Influence (SI) & 0.652 & 0.881 & 0.819 \\
\hline Facilatitaing Condition (FC) & 0.633 & 0.873 & 0.806 \\
\hline Behavioral Intention (BI) & 0.839 & 0.904 & 0.903 \\
\hline
\end{tabular}

AVE Average Variance Extracted; CR Composite Reliability; CA Cronbach's Alpha

\section{Discriminant Validity}

The next test is the discriminant validity or Fornell Lacker Criterium test. This test is done by looking at the cross loading value and the root square value of Average Variance Extracted / AVE. If every indicator that measures a construct has a greater crossload value to the construct, it can be said to be valid.
The results of this test indicate that the Root Square Value of AVE obtained by each construct is greater than the correlation value between the construct and other constructs in the same column. Therefore, discriminant validity requirements are also met. Data can be seen in the following Table 3 . 
Table-3: Discriminant Validity (Fornell Lacker Criterium)

\begin{tabular}{|c|c|c|c|c|c|}
\hline & PE & EE & SI & FC & BI \\
\hline Performance Expectancy (PE) & $\mathbf{0 . 7 3 6}$ & & & & \\
\hline Effort Expectancy (EE) & 0.619 & $\mathbf{0 . 8 8 9}$ & & & \\
\hline Service Influence (SI) & 0.499 & 0.615 & $\mathbf{0 . 8 0 7}$ & & \\
\hline Facilatitaing Condition (FC) & 0.535 & 0.660 & 0.618 & $\mathbf{0 . 7 9 6}$ & \\
\hline Behavioral Intention (BI) & 0.603 & 0.565 & 0.691 & 0.646 & $\mathbf{0 . 9 1 6}$ \\
\hline
\end{tabular}

\section{Hypothesis Test Results}

Hypothesis testing is done by SEM-PLS. In this study, the significance level used was $5 \%$. The hypothesis will be accepted if the $\mathrm{p}$-value $<0.05$. The path coefficient is used to determine the direction of the correlation coefficient. The results of positive correlation coefficient indicate that there is a positive relationship between constructs and likewise if the results of the negative correlation coefficient indicate a negative relationship. The research model will also be tested by looking at the coefficient of determination $\left(\mathrm{R}^{2}\right)$ which is between zero and one. This value explains the variation of the dependent variable. If it is zero then it cannot explain variation on the dependent variable, whereas if it is one, the independent variable explains one hundred percent variation on the dependent variable.

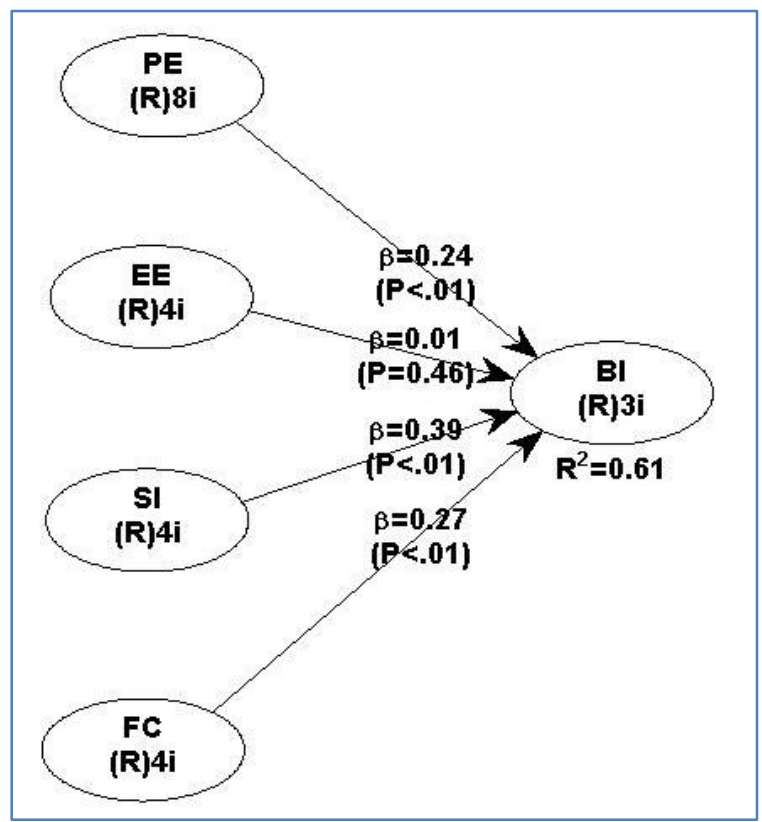

Fig-2: Hypothesis Test Result

Hypothesis test results indicate that there is a significant influence between performance expectancy and behavioral intention where $\mathrm{p}$-value $<0.01$ so that H1 is supported. Furthermore, the relationship between effort expectancy and behavioral intention has a $p$-value of 0.46 , so it can be stated that $\mathrm{H} 2$ is not supported. Not only performance expectancy, a significant influence was also found on social influence, where a p-value of $<0.01$, so that $\mathrm{H} 3$ was also supported. In addition, $\mathrm{H} 4$ also received support, or in other words there was a significant influence between facilitating conditions and behavioral intention. This is evidenced by the P-value facilitating conditions of $<0.01$. Other results note that the Adjusted R-squared Coefficient on behavioral intention is 0.61 , which means $61 \%$ of behavioral intention can be made by the variables of performance expectancy, effort expectancy, social influence, and facilitating conditions. The results of the hypotheses test are summarized in Table 4 as follows.

Table-4: Summary Structural Model

\begin{tabular}{|c|c|c|c|c|}
\hline Hypothesis & Description & Coefficient & P-value & Result \\
\hline H1 & PE $\rightarrow$ BI & 0.240 & $<0.01$ & Supported \\
\hline H2 & EE $\rightarrow$ BI & 0.010 & 0.46 & Not supported \\
\hline H3 & SI $\rightarrow$ BI & 0.300 & $<0.01$ & Supported \\
\hline H4 & FC $\rightarrow$ BI & 0.270 & $<0.01$ & Supported \\
\hline
\end{tabular}


For theoretical contribution, this study extends the general UTAUT concept in predicting technology adoption factors, especially in the context of social media application adoption among Indonesian SMEs. Based on empirical findings in this study, it is known that performance expectancy, social influence, and facilitating conditions had positive and significant effects on behavioral intention to use social media. The results of this study confirm the results of previous studies that found performance expectancy had significant effect on behavioral intention [26, 72, 29, 36], social influence had significant effect on behavioral intention[80, 67, 72] facilitationg condition had significant effect on behavioral intention [80, 67, 72]; but effort expectancy did not have significant effect on behavioral intention $[67,73,81]$.

\section{CONCLUSION}

The purpose of this study is to predict the factors that influence the adoption of social media among Indoneisan SMEs to promote and market their business with the Unified Theory of Acceptance and Use of Technology theory (UTAUT) approach. The findings of the study revealed that the model was able to explain $61 \%$ of the variance in behavioral intention. Result showed that the variables such as performance expectancy, social influence, and facilitating conditions had positive and significant effect on behavioral intention to use ride-hailing apps for buying food. Surprisingly, effort expectancy had no significant influence.

\section{REFERENCES}

1. Rekarti, E., \& Doktoralina, C. M. (2017). Improving Business Performance: A Proposed Model for SMEs. European Research Studies Journal Volume XX, Issue 3A. pp. 613-623.

2. Gama, P. D. A. (2011). An expanded model of marketing performance. Marketing Intelligence \& Planning, 29(7), 643-661.

3. Ainin, S. (2015). Factors influencing the use of social media by SMEs and its performance outcomes. Industrial Management \& Data Systems, 115(3), 570-588.

4. Surya, et al. (2020). Improving Brand and Marketing Performance of SMEs Through Social Media Usage: An Empirical Research. International Journal of Psychosocial Rehabilitation. Volume 24 - Issue 6

5. Ahmad, S. Z., Abu Bakar, A. R., \& Ahmad, N. (2019). Social media adoption and its impact on firm performance: the case of the UAE. International Journal of Entrepreneurial Behavior \& Research, 25(1), 84-111.

6. Ainin, S., Parveen, F., Moghavvemi, S., Jaafar, N. I., \& Mohd Shuib, N. L. (2015). Factors influencing the use of social media by SMEs and its performance outcomes. Industrial Management \& Data Systems, 115(3), 570-588.
7. Charoensukmongkol, P., \& Sasatanun, P. (2017). Social media use for CRM and business performance satisfaction: The moderating roles of social skills and social media sales intensity. Asia Pacific Management Review, 22(1), 25-34.

8. Musa. (2016). Social Media Marketing and Online Small and Medium Enterprises Performance: Perspective of Malaysian Small and Medium Enterprises. International Review of Management and Marketing Intelligence \& Planning, 6(7), 1-5.

9. Nuseir, M. T. (2018). Digital media impact on SMEs performance in the UAE. Academy of Entrepreneurship Journal, 24(2), 1-13.

10. Odoom, R., Anning-Dorson, T., \& Acheampong, G. (2017). Antecedents of social media usage and performance benefits in small- and medium-sized enterprises (SMEs). Journal of Enterprise Information Management, 30(3), 383-399.

11. Crammond, R., Omeihe, K. O., Murray, A., \& Ledger, K. (2018). Managing knowledge through social media. Baltic Journal of Management, 13(3), 303-328

12. L'Écuyer, F., \& Pelletier, C. (2019). Exploration of Social Media Capabilities for Recruitment in SMEs: A Multiple Case Study. 221-239.

13. Papa, A., Santoro, G., Tirabeni, L., \& Monge, F. (2018). Social media as tool for facilitating knowledge creation and innovation in small and medium enterprises. Baltic Journal of Management, 13(3), 329-344.

14. Dahnil, M. I., Marzuki, K. M., Langgat, J., \& Fabeil, N. F. (2014). Factors Influencing SMEs Adoption of Social Media Marketing. Procedia Social and Behavioral Sciences, 148, 119-126.

15. Durkin, M., McGowan, P., \& McKeown, N. (2013). Exploring social media adoption in small to medium-sized enterprises in Ireland. Journal of Small Business and Enterprise Development.

16. Gavino, M. C., Williams, D. E., Jacobson, D., \& Smith, I. (2019). Latino entrepreneurs and social media adoption: personal and business social network platforms. Management Research Review, 42(4), 469-494.

17. Mack, E. A., Marie-Pierre, L., \& Redican, K. (2017). Entrepreneurs' use of internet and social media applications. Telecommunications Policy, 41(2), 120-139.

18. Sarosa, S. (2012). Adoption of Social Media Networks by Indonesian SME: A Case Study. Procedia Economics and Finance, 4, 244-254.

19. Ahmad, S. Z., Ahmad, N., \& Abu Bakar, A. R. (2018). Reflections of entrepreneurs of small and medium-sized enterprises concerning the adoption of social media and its impact on performance outcomes: Evidence from the UAE. Telematics and Informatics, 35(1), 6-17.

20. AlSharji, A., Ahmad, S. Z., \& Bakar, A. R. A. (2018). Understanding social media adoption in SMEs. Journal of Entrepreneurship in Emerging Economies. 
21. Bakri. (2017). The impact of social media adoption on competitive advantage in the small and medium enterprises. Int. J. Business Innovation and Research, 13(2), 255-269.

22. Trainor, K. J., Andzulis, J., Rapp, A., \& Agnihotri, R. (2014). Social media technology usage and customer relationship performance: A capabilitiesbased examination of social CRM. Journal of Business Research, 67(6), 1201-1208.

23. Venkatesh, V., Morris, M. G., Davis, G. B., \& Davis, F. D. (2003). User acceptance of information technology: Toward a unified view. MIS quarterly, 425-478.

24. Shiferaw., \& Mehari. (2019). Modeling predictors of acceptance and use of electronic medical record system in a resource limited setting: Using modified UTAUT model. Informatics in Medicine.

25. Ramírez-Correa, P., Rondán-Cataluña, F. J., Arenas-Gaitán, J., \& Martín-Velicia, F. (2019). Analysing the acceptation of online games in mobile devices: An application of UTAUT2. Journal of Retailing and Consumer Services, 50, 85-93.

26. Farah, M. F., Hasni, M. J. S., \& Abbas, A. K. (2018). Mobile-banking adoption: empirical evidence from the banking sector in Pakistan. International Journal of Bank Marketing, 36(7), 1386-1413.

27. Giovanis. (2018). Adoption of mobile self-service retail banking technologies: The role of technology, social, channel and personal factorsI. International Journal of Retail \& Distribution Management.

28. Giovanis, A., Athanasopoulou, P., \& Assimakopoulos, C. (2019). Adoption of mobile banking services. International Journal of Bank Marketing, 37(5), 1165-1189.

29. Raza, Shah, \& Ali. (2018). Acceptance of mobile banking in Islamic banks: evidence from modified UTAUT mode. Journal of Islamic Marketing.

30. Tan. (2016). Behavioural intention to adopt mobile banking among the millennial generation. Young Consumers, Vol. 17 (Iss 1 ).

31. Abrahão, R. d. S., Moriguchi, S. N., \& Andrade, D. F. (2016). Intention of adoption of mobile payment: An analysis in the light of the Unified Theory of Acceptance and Use of Technology (UTAUT). RAI Revista de Administração e Inovação, 13(3), 221230.

32. Cao, Q., \& Niu, X. (2019). Integrating contextawareness and UTAUT to explain Alipay user adoption. International Journal of Industrial Ergonomics, 69, 9-13.

33. Khalilzadeh, J., Ozturk, A. B., \& Bilgihan, A. (2017). Security-related factors in extended UTAUT model for NFC based mobile payment in the restaurant industry. Computers in Human Behavior, 70, 460-474.

34. Sobti. (2019). Impact of demonetization on diffusion of mobile payment service in India Antecedents of behavioral intention and adoption using extended UTAUT model. Journal of Advances in Management Research News.

35. Tak. (2017). Using UTAUT 2 Model to Predict Mobile App based shopping: Evidences from India. Journal of Indian Business Research.

36. Yang. (2010). Determinants of US consumer mobile shopping services adoption: implications for designing mobile shopping services. Journal of Consumer Marketing, Vol. 27( Iss 3), pp. 262 - 270.

37. Chhonker, M. S., Verma, D., \& Kar, A. K. (2017). Review of Technology Adoption frameworks in Mobile Commerce. Procedia Computer Science, $122,888-895$.

38. Chang. (2013). Library mobile applications in university libraries. Library Hi Tech, Vol. 31(Iss 3), pp. 478 - 492.

39. Dwivedi, Y. K., Shareef, M. A., \& Simintiras, A. C. (2016). A generalised adoption model for services: A cross-country comparison of mobile health (mhealth). Government Information Quarterly, 33(1), 174-187.

40. Hoque, R., \& Sorwar, G. (2017). Understanding factors influencing the adoption of mHealth by the elderly: An extension of the UTAUT model. Int $J$ Med Inform, 101, 75-84.

41. Okumus, Bilgihan, \& Ozturk. (2018). Psychological factors influencing customers' acceptance of smartphone diet apps when ordering food at restaurants. International Journal of Hospitality Management, 72, 67-77.

42. Chua, P. Y., Rezaei, S., \& Gu, M.-L. (2018). Elucidating social networking apps decisions. Nankai Business Review International, 9(2), 118142.

43. El Ouirdi, M., El Ouirdi, A., \& Segers, J. (2016). Technology adoption in employee recruitment: The case of social media in Central and Eastern Europe. Computers in Human Behavior, 57, 240-249.

44. Herrero, A., San Martín, H., \& Collado, J. (2018). Market orientation and SNS adoption for marketing purposes in hospitality microenterprises. Journal of Hospitality and Tourism Management, 34, 30-40.

45. Nawi. (2017). The acceptance and usage of social media as a platform among student entrepreneurs. Journal of Small Business and Enterprise Development, 24(2).

46. Fong, L. H. N., Lam, L. W., \& Law, R. (2017). How locus of control shapes intention to reuse mobile apps for making hotel reservations: Evidence from chinese consumers. Tourism Management, 61, 331-342.

47. Kuciapski. (2017). A model of mobile technologies acceptance for knowledge transfer by employees. Journal of Knowledge Management Decision.

48. Thongsri. (2018). Integrating UTAUT and UGT to explain behavioural intention to use M-learning: A developing country's perspective. Journal of Systems and Information Technology, 20(3), 278297. 
49. Fleury, S. (2017). What drives corporate carsharing acceptance? A French case study. Transportation Research Part F: Traffic Psychology and Behaviour, 45, 218-227.

50. Chiao, H.-M., Chen, Y.-L., \& Huang, W.-H. (2018). Examining the usability of an online virtual tourguiding platform for cultural tourism education. Journal of Hospitality, Leisure, Sport \& Tourism Education, 23, 29-38.

51. Cabrera-Sánchez, J.-P., \& Villarejo-Ramos, Á. F. (2020). Acceptance and use of big data techniques in services companies. Journal of Retailing and Consumer Services, 52, 101888.

52. zhou. (2019). Understanding urban delivery drivers' intention to adopt electric trucks in China. Transportation Research (2019), 74(Part D), 6581.

53. AbuShanab, E., \& Pearson, J. M. (2007). Internet banking in Jordan: The unified theory of acceptance and use of technology (UTAUT) perspective. Journal of Systems and Information Technology, 9(1), 78-97.

54. Rahi, \& Ghani. (2019). Investigating the role of UTAUT and e-service quality in internet banking adoption setting. The TQM Journal, 31(3), 491-506.

55. Yaseen, S. G., \& El Qirem, I. A. (2018). Intention to use e-banking services in the Jordanian commercial banks. International Journal of Bank Marketing.

56. Ahmad, Markkula, \& Oivo. (2013). Factors affecting e-government adoption in Pakistan: a citizen's perspective. Transforming Government: People, Process and Policy, 7(2), 225-239.

57. Berlilana, Hariguna, \& Nurfaizah. (2017). Understanding of Public Behavioral Intent to Use e-Government Service: An Extended of Unified Theory of Acceptance Use of Technology and Information System Quality. Procedia Computer Science, 124, 585-592.

58. Mansoori, K. A. A., Sarabdeen, J., \& Tchantchane, A. L. (2018). Investigating Emirati citizens' adoption of e-government services in Abu Dhabi using modified UTAUT model. Information Technology \& People, 31(2), 455-481.

59. Saxena, \& Janssen. (2017). Examining Open Government Data (OGD) usage in India through UTAUT framework. foresight.

60. Talukder. (2018). Determinants of user acceptance and use of open government data (OGD): An empirical investigation in Bangladesh. Technology in Society.

61. Chauhan, S., \& Jaiswal, M. (2016). Determinants of acceptance of ERP software training in business schools: Empirical investigation using UTAUT model. The International Journal of Management Education, 14(3), 248-262.

62. Keong, L. M., Ramayah, T., Kurnia, S., \& May Chiun, L. (2012). Explaining intention to use an enterprise resource planning (ERP) system: an extension of the UTAUT model. Business Strategy Series, 13(4), 173-180.

63. Urumsah. (2015). Factors Influencing Consumers to Use e-services in Indonesian Airline Companies In E-services Adoption: Processes by Firms in Developing Nations., 5-254.

64. Madigan, R., Louw, T., Dziennus, M., Graindorge, T., Ortega, E., Graindorge, M., \& Merat, N. (2016). Acceptance of Automated Road Transport Systems (ARTS): An Adaptation of the UTAUT Model. Transportation Research Procedia, 14, 2217-2226.

65. Bawack, R. E., \& Kala Kamdjoug, J. R. (2018). Adequacy of UTAUT in clinician adoption of health information systems in developing countries: The case of Cameroon. Int J Med Inform, 109, 1522.

66. Emmert, M., \& Wiener, M. (2017). What factors determine the intention to use hospital report cards? The perspectives of users and non-users. Patient Educ Couns, 100(7), 1394-1401.

67. Hossain, A., Quaresma, R., \& Rahman, H. (2019). Investigating factors influencing the physicians' adoption of electronic health record (EHR) in healthcare system of Bangladesh: An empirical study. International Journal of Information Management, 44, 76-87.

68. Kalavani, A., Kazerani, M., \& Shekofteh, M. (2018). Acceptance of evidence based medicine (EBM) databases by Iranian medical residents using unified theory of acceptance and use of technology (UTAUT). Health Policy and Technology, 7(3), 287-292.

69. Reyes-Mercado. (2018). Adoption of fitness wearables: Insights from Partial Least Squares and Qualitative Comparative Analysis. Journal of Systems and Information Technology.

70. Carter, L., Christian Shaupp, L., Hobbs, J., \& Campbell, R. (2011). The role of security and trust in the adoption of online tax filing. Transforming Government: People, Process and Policy, 5(4), 303-318.

71. Hsiao, \& Tang. (2014). Explaining undergraduates' behavior intention of e-textbook adoption Empirical assessment of five theoretical models. Library Hi Tech, 32(1), pp. 139-163.

72. Hsu, C.-L., Lin, Y.-H., Chen, M.-C., Chang, K.-C., \& Hsieh, A.-Y. (2017). Investigating the determinants of e-book adoption. Program, 51(1), 2-16.

73. Madigan, R., Louw, T., Wilbrink, M., Schieben, A., \& Merat, N. (2017). What influences the decision to use automated public transport? Using UTAUT to understand public acceptance of automated road transport systems. Transportation Research Part F: Traffic Psychology and Behaviour, 50, 55-64.

74. Rezaei, \& Ghofranfarid. (2018). Rural households' renewable energy usage intention in Iran: Extending the unified theory of acceptance and use of technology. Renewable Energy. 
75. Zhou. (2020). Understanding consumers' behavior to adopt self-service parcel services for last-mile delivery. Journal of Retailing and Consumer Services, 52.

76. Gupta, K. P., Manrai, R., \& Goel, U. (2019). Factors influencing adoption of payments banks by Indian customers: extending UTAUT with perceived credibility. Journal of Asia Business Studies, 13(2), 173-195.

77. Arif, M., Ameen, K., \& Rafiq, M. (2018). Factors affecting student use of Web-based services. The Electronic Library, 36(3), 518-534.

78. Kurfalı, M., Arifoğlu, A., Tokdemir, G., \& Paçin, Y. (2017). Adoption of e-government services in Turkey. Computers in Human Behavior, 66, 168178.

79. Shamim, S., Zeng, J., Shariq, S. M., \& Khan, Z. (2019). Role of big data management in enhancing big data decision-making capability and quality among Chinese firms: A dynamic capabilities view. Information \& Management, 56(6), 103135.

80. Farooq, M. S., Salam, M., Jaafar, N., Fayolle, A., Ayupp, K., Radovic-Markovic, M., \& Sajid, A. (2017). Acceptance and use of lecture capture system (LCS) in executive business studies. Interactive Technology and Smart Education, 14(4), 329-348.

81. Naranjo-Zolotov, Oliveira, \& Casteleyn. (2019). Citizens' intention to use and recommend eparticipation. Drawing upon UTAUT and citizen empowerment. Information Technology \& People, 32(2), 364-386.

82. Borgen, S. O., \& Aarset, B. (2016). Participatory Innovation: Lessons from breeding cooperatives. Agricultural Systems, 145, 99-105. 